Supporting Information

\title{
A Mitochondrial-Targeting Near-Infrared Fluorescent Probe for Visualizing and Monitoring Viscosity in Live Cells and Tissues
}

Yuying Zhang, Zhen Li, Wei Hu, Zhihong Liu*

Key Laboratory of Analytical Chemistry for Biology and Medicine (Ministry of Education), College of Chemistry and Molecular Sciences, Wuhan University, Wuhan 430072, China.

*Corresponding author: Zhihong Liu

Fax: 86-27-68754067

Email: zhhliu@whu.edu.cn 


\section{Table of contents}

Table S1. Reported representative fluorescent probes for mitochondrial viscosity.

\section{Reagents and Apparatus}

Figure S1. Absorption spectra of NI-VIS in the solvent of low viscosity and high viscosity.

Figure S2. Fluorescence emission spectra and UV-Vis spectra of NI-VIS in different solvents.

Figure S3. Frontier molecular orbitals of NI-VIS acquired via quantum-chemical calculation.

Figure S4. pH stability of the probe.

Figure S5. Selectivity of the probe to viscosity against other distractions.

Figure S6. Cell viability assay.

Figure S7. Z-direction slices of confocal luminescence imaging for mouse liver tissues.

Figure S8. ${ }^{1} \mathrm{H}$ NMR of the NIR probe.

Figure S9. ${ }^{13} \mathrm{C}$ NMR of the NIR probe.

Figure S10. ESI mass spectrum of the NIR probe.

\section{References}


Table S1. Reported representative fluorescent probes for mitochondrial viscosity

\begin{tabular}{|c|c|c|c|c|c|c|}
\hline Probes & $\lambda \mathrm{ex} / \mathrm{nm}$ & $\lambda \mathrm{em} / \mathrm{nm}$ & $\begin{array}{l}\text { Quantum } \\
\text { yield }\end{array}$ & $\mathrm{LOD} / \mathrm{cP}$ & $\begin{array}{l}\text { Response } \\
\text { multiple }\end{array}$ & $\begin{array}{l}\text { Bioimaging } \\
\text { application }\end{array}$ \\
\hline MitoAIE1 $^{1}$ & 450 & 625 & $\sim$ & 0.6 & 14-fold & Cell \\
\hline Caz-Cy2 ${ }^{2}$ & 480 & $380 / 580$ & $0.012-0.04$ & 1.0 & 80 -fold & $\begin{array}{l}\text { Cell, } \\
\text { Rat hepar } \\
\text { slice }\end{array}$ \\
\hline Mito-V³ & 405 & 658 & $\begin{array}{l}0.0004 \text { at } 467 \\
\mathrm{~nm} ; 0.01 \text { at } \\
660 \mathrm{~nm} \mathrm{in} \\
\text { water }\end{array}$ & 1.1 & 8.8-fold & Cell \\
\hline $\mathrm{TDHC}^{4}$ & 525 & 600 & $\sim$ & $1-2$ & $>4$-fold & $\begin{array}{l}\text { Cell, } \\
\text { Primary } \\
\text { cortical } \\
\text { neurons }\end{array}$ \\
\hline BTV $^{5}$ & 470 & 515 & $0.01-0.56$ & 0.6 & > 100-fold & Cell \\
\hline Mito-VS ${ }^{6}$ & 500 & 610 & $\begin{array}{l}0.62 \text { in } \\
\text { glycero; } \\
<0.02 \quad \text { in } \\
\text { ethanol }\end{array}$ & 1.03 & 10-fold & Cell \\
\hline NI-VIS & 560 & 670 & $\begin{array}{l}0.23 \text { in } \\
\text { glycero; } \\
<0.01 \text { in } \\
\text { DPBS }\end{array}$ & 1.0 & 167-fold & $\begin{array}{l}\text { Cell, } \\
\text { Zebrafish, } \\
\text { Liver tissues }\end{array}$ \\
\hline
\end{tabular}

Reagents and Apparatus: Water was purified and doubly distilled by a Milli-Q system (Millipore, USA). All chemicals were purchased from Shanghai Chemical Reagent Corporation as analtical grade and used without further purification. The one-photon excited fluorescence measurements were conducted at room temperature on a Fluoromax-4 spectrofluorometer (HORIBA JobinYvon, Edison, NJ) with both excitation and emission slit 
set at $10.0 \mathrm{~nm}$. Mass spectra were performed using an LCQ Advantage ion trap mass spectrometer (Thermo Finnigan). NMR spectra were recorded on a Bruker DRX-400 spectrometer using TMS as an internal standard. All chemical shifts are reported in the standard $\delta$ notation of parts per million. Two-photon fluorescence images of cells and tissues were obtained using an Olympus FV1000-MPE multiphoton laser Scanning confocal microscope (Japan).

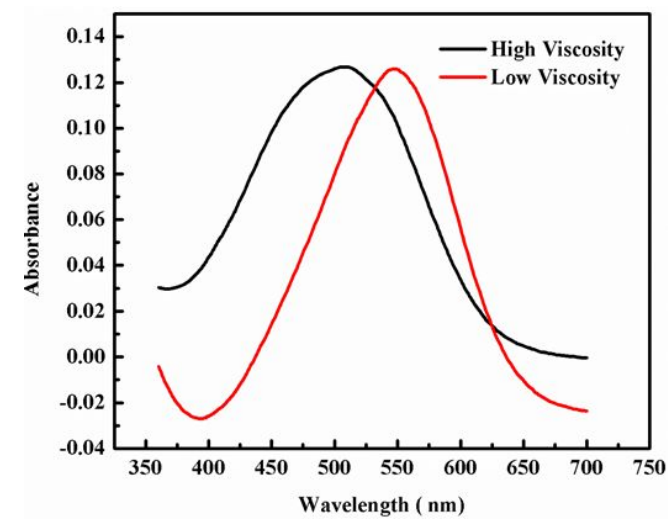

Figure S1. Absorption spectra of NI-VIS $(10 \mu \mathrm{M})$ in the solvent of low viscosity $(1.0 \mathrm{cP}$, red line $)$ and high viscosity (999 cP, black line ).
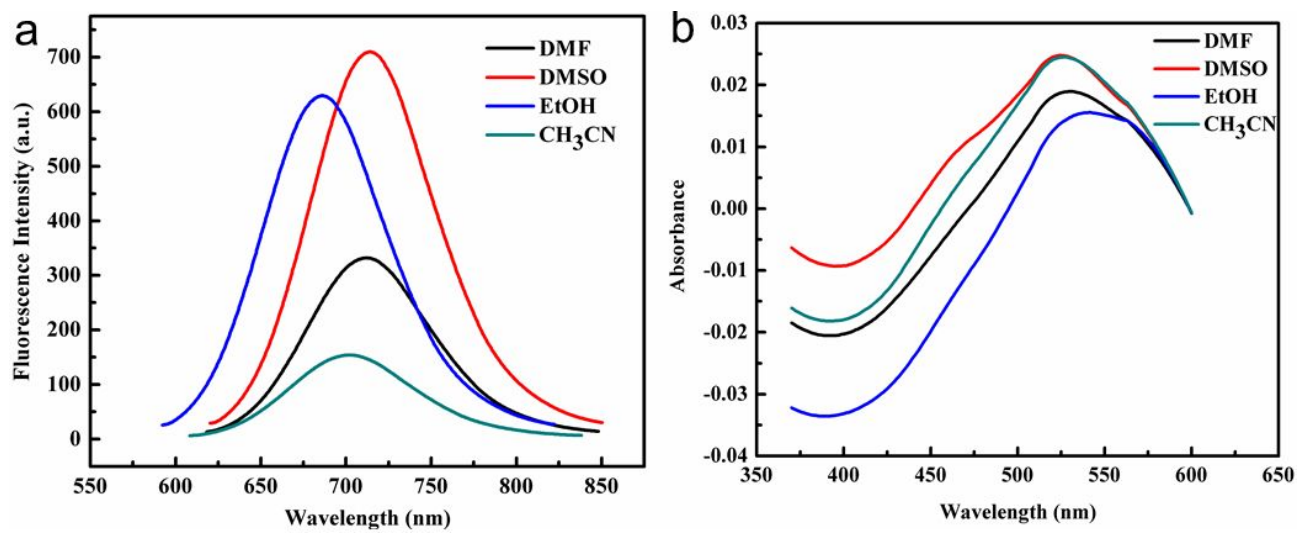

Figure S2. (a) Fluorescence emission spectra and (b) UV-Vis spectra of NI-VIS $(10 \mu \mathrm{M})$ in different solvents, $\lambda_{\text {ex }}=560 \mathrm{~nm}$. 

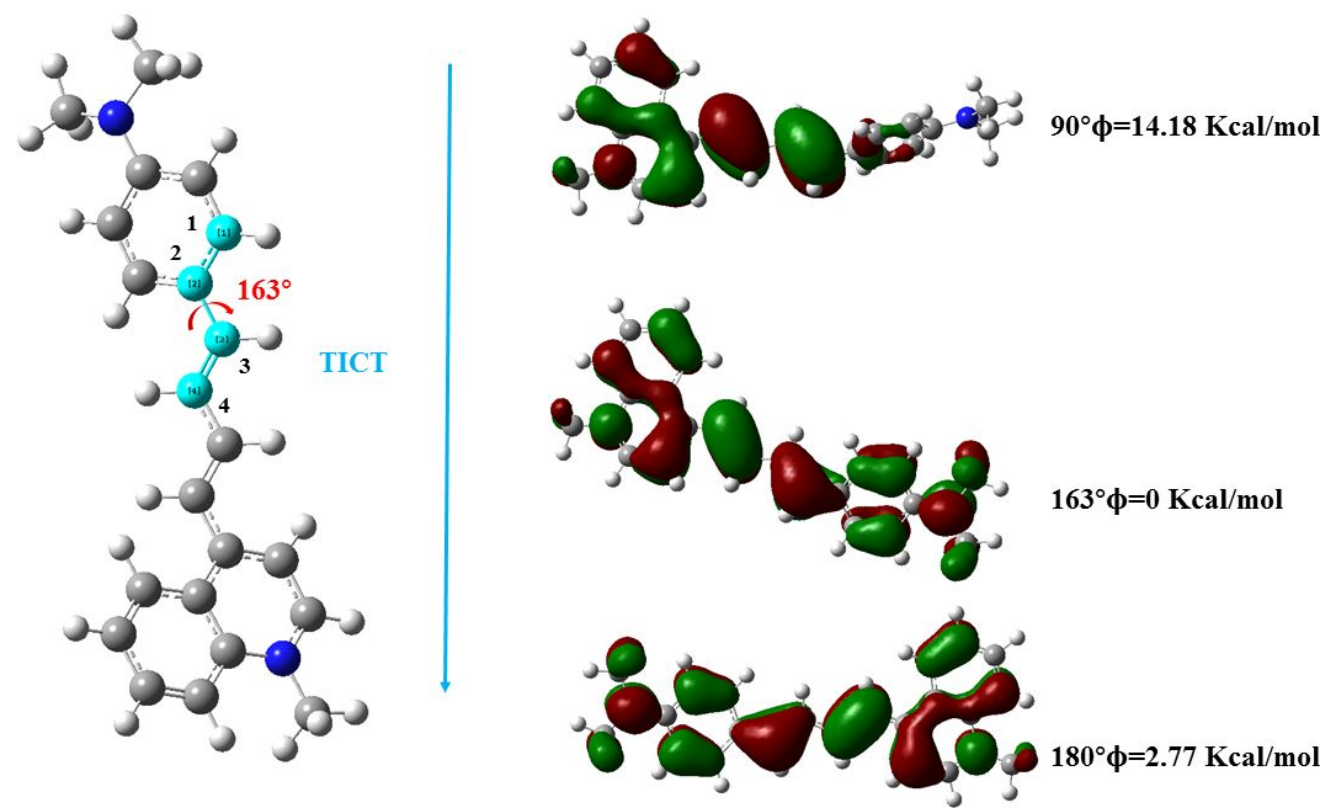

Figure S3. Frontier molecular orbitals of NI-VIS acquired via quantum-chemical calculation.

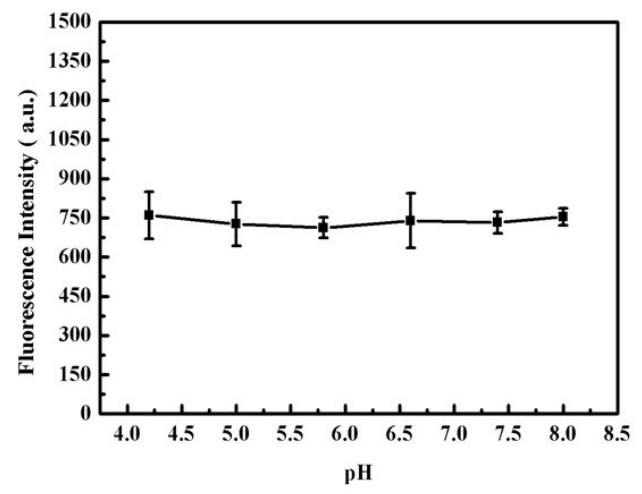

Figure S4. Fluorescence intensity response of the NI-VIS $(10 \mu \mathrm{M})$ carry out in phosphate buffered solution $(10 \mathrm{mM})$ with different $\mathrm{pH}(4.2,5.0,5.8,6.6,7.4,8.0)$. According to the relationship described by the Forster-Hoffmann equation, viscosity values is 8.19 a.u. $\lambda_{\text {ex }}$ $=560 \mathrm{~nm}$.

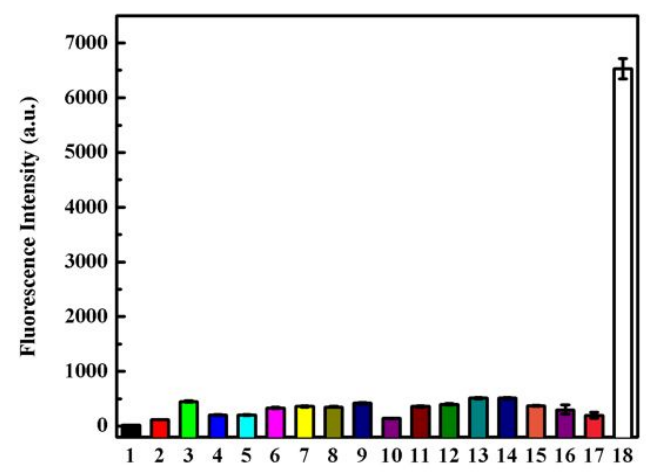

Figure S5. Fluorescence response of NI-VIS $(10 \mu \mathrm{M})$ toward various analytes. The 
fluorescence intensity was plotted versus substances: 1-17. $\mathrm{NaCl}, \mathrm{KCl}, \mathrm{FeSO}_{4}, \mathrm{CuSO}_{4}, \mathrm{CaCl}_{2}$, $\mathrm{ZnCl}_{2}, \mathrm{H}_{2} \mathrm{O}_{2}, \mathrm{ONOO}^{-}, \mathrm{NaClO}, \mathrm{KO}_{2}, \cdot \mathrm{OH}, \mathrm{NO}, \mathrm{NaHSO}_{3}, \mathrm{NaHS}, \mathrm{Na}_{2} \mathrm{~S}_{2}, \mathrm{Cys}, \mathrm{GSH}(50 \mu \mathrm{M})$; 18. viscosity.

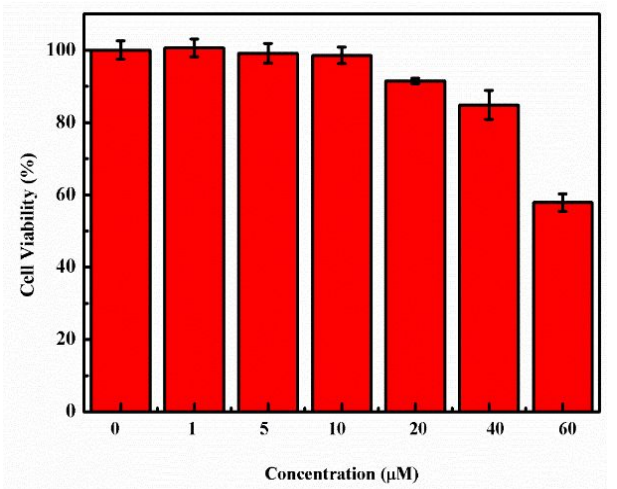

Figure S6. HeLa cells viability after incubated with NI-VIS in different concentration, $0 \mu \mathrm{M}$, $1 \mu \mathrm{M}, 5 \mu \mathrm{M}, 10 \mu \mathrm{M}, 20 \mu \mathrm{M}, 40 \mu \mathrm{M}$, and $60 \mu \mathrm{M}$. 


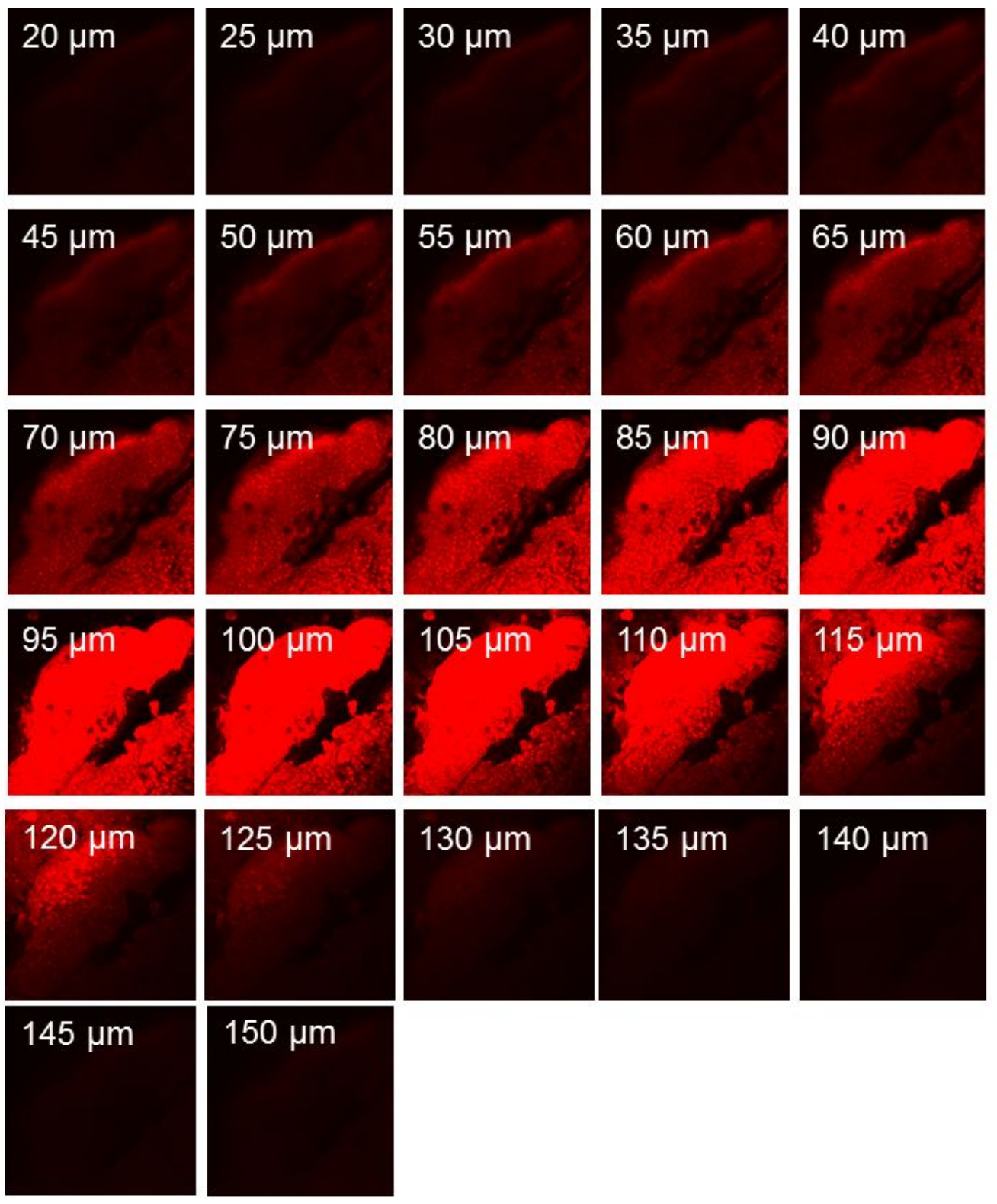

Figure S7. Depth fluorescence images of NI-VIS $(50 \mu \mathrm{M})$ in mouse liver tissues. The changes of fluorescence intensity with scan depth were determined by spectral confocal microscopy (Olympus, FV1000). $\lambda_{\mathrm{ex}}=560 \mathrm{~nm}, \lambda_{\mathrm{em}}=600-800 \mathrm{~nm}$. 


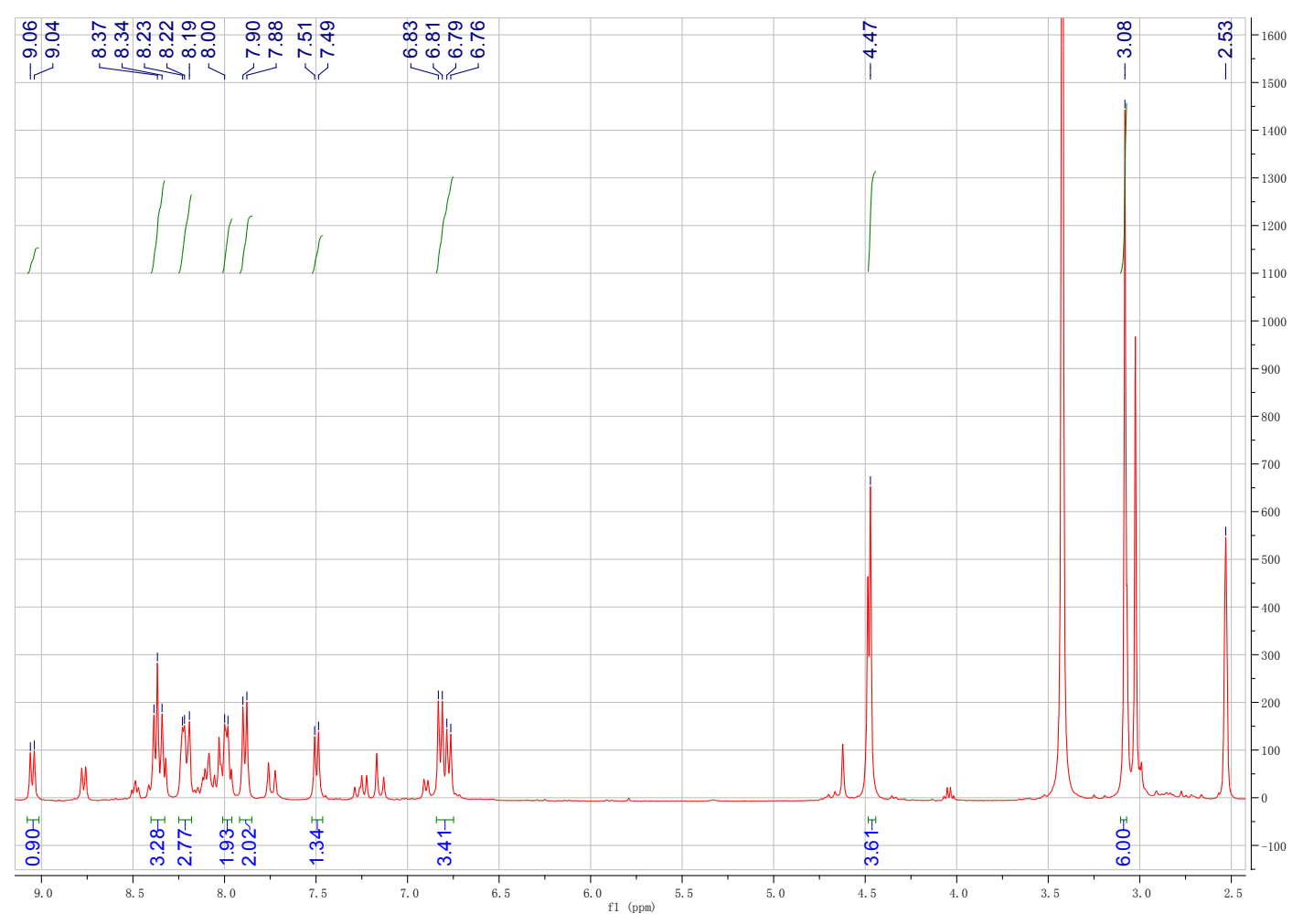

Figure S8. ${ }^{1} \mathrm{H}$ NMR of the NIR probe. 


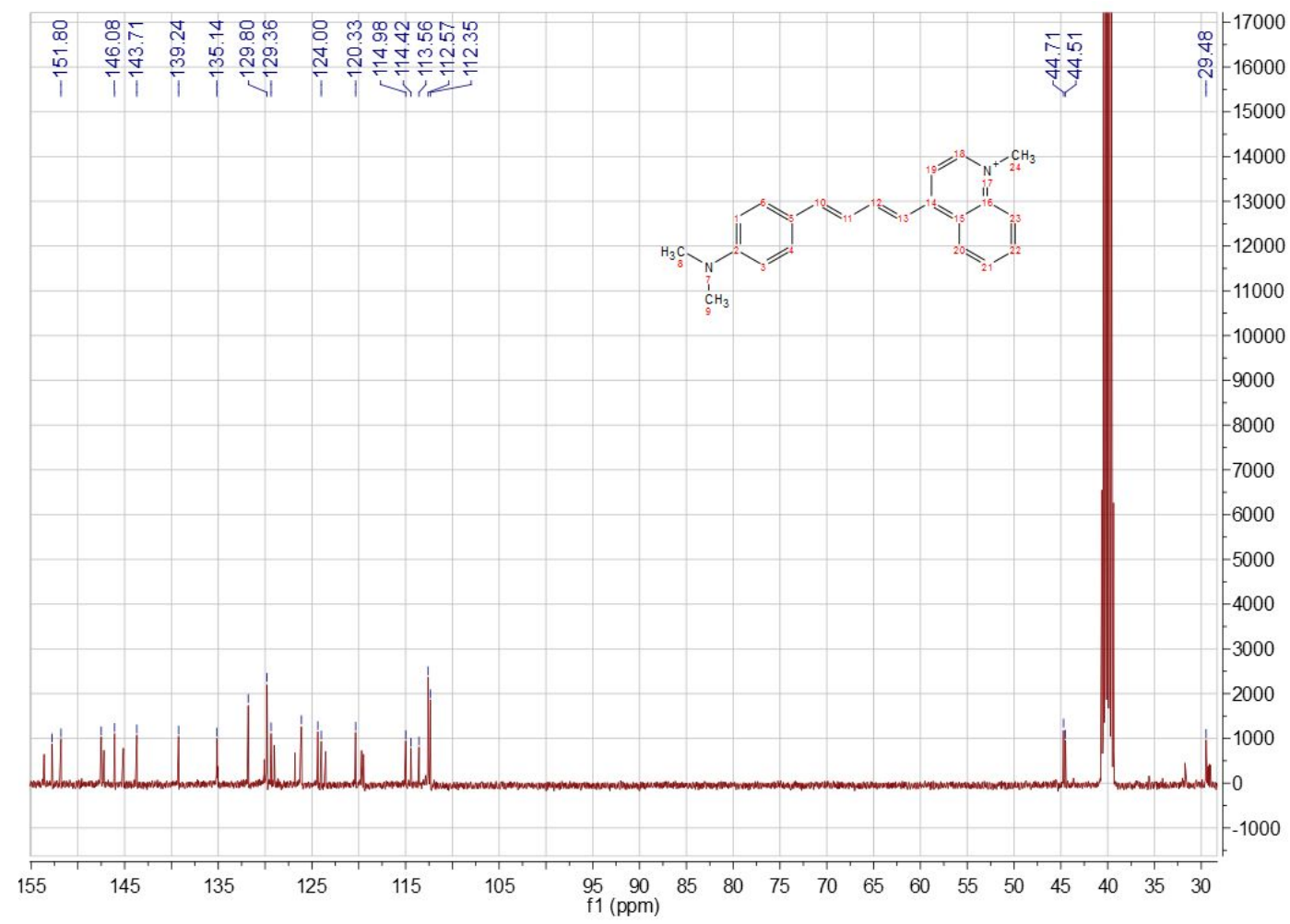

Figure S9. ${ }^{13} \mathrm{C}$ NMR of the NIR probe 


\begin{tabular}{|c|c|c|c|c|c|}
\hline \multicolumn{6}{|c|}{ Acquisition Parameter } \\
\hline Source Type & ESI & Ion Polarity & Positive & Set Nebulizer & $2.0 \mathrm{Bar}$ \\
\hline Focus & Not active & Set Capillary & $4500 \mathrm{~V}$ & Set Dry Heater & $200^{\circ} \mathrm{C}$ \\
\hline Scan Begin & $50 \mathrm{~m} / \mathrm{z}$ & Set End Plate Offset & $-500 \mathrm{~V}$ & Set Dry Gas & $8.0 \mathrm{~V} / \mathrm{min}$ \\
\hline Scan End & $1500 \mathrm{~m} / \mathrm{z}$ & Set Charging Voltage & $2000 \mathrm{~V}$ & Set Divert Valve & Waste \\
\hline & & Set Corona & $\mathrm{OnA}$ & Set APCI Heater & \\
\hline
\end{tabular}

+MS, 0.2-0.4min \#11-25

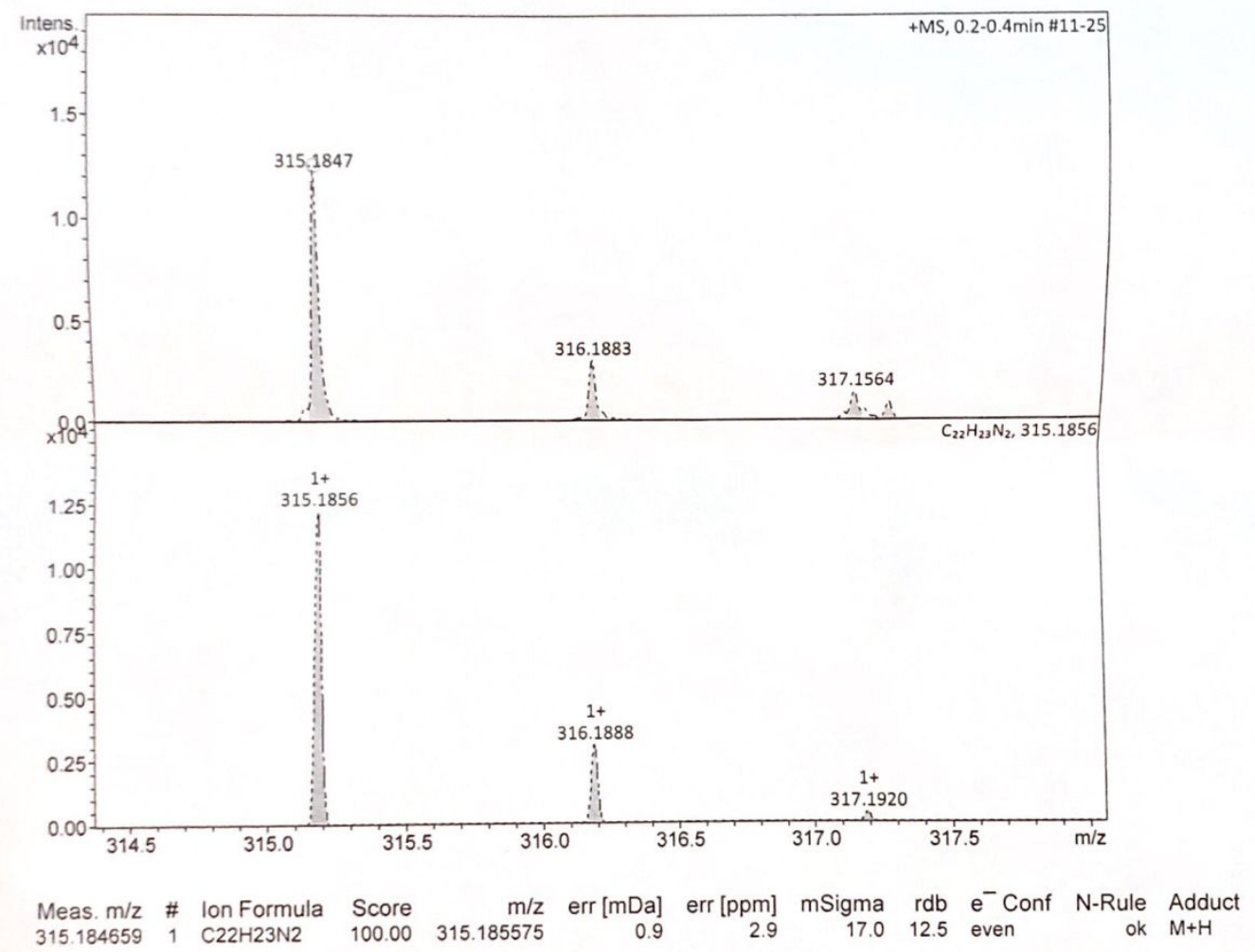

Figure S10. ESI mass spectrum of the NIR probe. 


\section{References}

1. Chen, W.; Gao, C.; Liu, X.; Liu, F.; Wang, F.; Tang, L.-J.; Jiang, J.-H., Engineering organelle-specific molecular viscosimeters using aggregation-induced emission luminogens for live cell imaging. Analytical chemistry 2018, 90 (15), 8736-8741.

2. Liu, F.; Wu, T.; Cao, J.; Cui, S.; Yang, Z.; Qiang, X.; Sun, S.; Song, F.; Fan, J.; Wang, J., Ratiometric detection of viscosity using a two - photon fluorescent sensor. Chemistry - A European Journal 2013, 19 (5), 1548-1553.

3. Jiang, N.; Fan, J.; Zhang, S.; Wu, T.; Wang, J.; Gao, P.; Qu, J.; Zhou, F.; Peng, X., Dual mode monitoring probe for mitochondrial viscosity in single cell. Sensors and Actuators B: Chemical 2014, 190, 685-693.

4. Baek, Y.; Park, S. J.; Zhou, X.; Kim, G.; Kim, H. M.; Yoon, J., A viscosity sensitive fluorescent dye for real-time monitoring of mitochondria transport in neurons. Biosensors and Bioelectronics 2016, 86, 885-891. 5. Su, D.; Teoh, C.; Gao, N.; Xu, Q.-H.; Chang, Y.-T., A simple BODIPY-based viscosity probe for imaging of cellular viscosity in live cells. Sensors 2016, 16 (9), 1397.

6. Li, S.-J.; Li, Y.-F.; Liu, H.-W.; Zhou, D.-Y.; Jiang, W.-L.; Ou-Yang, J.; Li, C.-Y., A dual-response fluorescent probe for the detection of viscosity and $\mathrm{H} 2 \mathrm{~S}$ and its application in studying their cross-talk influence in mitochondria. Analytical chemistry 2018, 90 (15), 9418-9425. 